Max-Planck-Institut für demografische Forschung

Max Planck Institute for Demographic Research

Konrad-Zuse-Strasse 1 - D-18057 Rostock - GERMANY

Tel +49 (0) 3812081 - 0; Fax +49 (0) 3812081 - 202;

http://www.demogr.mpg.de

MPIDR WORKING PAPER WP 2003-001

JANUARY 2003

\title{
Childrearing responsibility
} and stepfamily fertility in Finland and Austria

\author{
Andres Vikat (vikat@demogr.mpg.de) \\ Elizabeth Thomson (thomson@ssc.wisc.edu) \\ Alexia Prskawetz (fuernkranz@demogr.mpg.de)
}

(c) Copyright is held by the authors.

Working papers of the Max Planck Institute for Demographic Research receive only limited review.

Views or opinions expressed in working papers are attributable to the authors and do not necessarily reflect those of the Institute. 


\title{
Childrearing Responsibility and Stepfamily Fertility in Finland and Austria
}

\author{
Andres Vikat \\ Max Planck Institute for Demographic Research, Rostock, Germany \\ Elizabeth Thomson \\ Department of Sociology, and Center for Demography and Ecology, University of Wisconsin- \\ Madison, Madison, Wisconsin \\ Alexia Prskawetz \\ Max Planck Institute for Demographic Research, Rostock, Germany
}

Contact information:

Andres Vikat

Max Planck Institute for Demographic Research

Konrad-Zuse-Strasse 1

D-18057 Rostock, Germany

Tel +493812081194

Fax +493812081494

vikat@demogr.mpg.de 


\title{
Childrearing Responsibility and Stepfamily Fertility in Finland and Austria
}

\begin{abstract}
We investigate the hypothesis that the propensity of a stepfamily couple to have a shared child is inversely related to the responsibility for rearing pre-union children. We compare effects of coresident pre-union children to those of nonresident, and effects of the woman's children to those of the man's. Our investigation is based on data from Finland and Austria, societies with different levels of public support for childrearing and different levels of gender equality. Shared children and stepchildren reduce the risk of a birth to a couple, and in line with a common finding in most stepfamily fertility studies, the reduction is larger for each shared child than for a stepchild. We found larger effects of coresident pre-union children than of nonresident children, and larger effects of a woman's pre-union children than of a man's. The differences were more pronounced in Austria where public support for childrearing and gender equality is lower than in Finland. Our study demonstrates that in addition to the number of pre-union children, coresidence and parentage of pre-union children also need to be considered in future fertility research.
\end{abstract}




\section{Introduction}

High rates of separation, divorce and repartnering have changed the family context of childbearing. Increasing proportions of couples are making childbearing decisions in stepfamilies, i.e., in unions where one or the other partner has children from a previous union. Research on stepfamily fertility usually finds that stepchildren lower the chances of the couple having children together, but that the effect of a stepchild is not as strong as that of a shared child on the couple's subsequent childbearing. One interpretation of these results is that shared births have a unique value that overcomes the costs of rearing a larger number of children. Another is that, on average, couples have less responsibility for rearing stepchildren than they do for shared children, so that the cost-benefit calculation favors further childbearing.

In this paper, we investigate the childrearing responsibility hypothesis, which says that the propensity of a stepfamily couple to have a shared child is inversely related to the responsibility for rearing their pre-union children. We identify indicators of variation in childrearing responsibility at the couple level and at the societal level. At the couple level, we compare effects of coresident pre-union children to those of nonresident, and effects of the woman's children to those of man's. We also compare two societies, Austria and Finland, with different levels of public support for childrearing and different levels of gender equality.

\section{Stepfamily Childbearing: Costs and Benefits}

When stepfamily couples have a child together, they incur the costs of a larger total family size (her + his + their children) than do couples without stepchildren and the same number of shared children. If costs and benefits of stepchildren and shared children were identical, we would expect childbearing in stepfamilies to follow a pattern of parity progression based on the couple's combined number of children. For example, we would expect couples with one stepchild and no shared children, and couples with a shared child and no stepchildren to have the same probability of having another child. Studies of stepfamily fertility demonstrate clearly, however, that stepchildren are not equivalent to shared children in their effects on a couple's subsequent childbearing. In general, stepchildren reduce their parent's birth risk less than do shared children, particularly if they number two or more (Toulemon 1997; Vikat, Thomson and Hoem 1999; Thomson et al. 2002). Griffith, Koo and Suchindran (1985) argued that the 'extra' childbearing in stepfamilies arises from unique values of a first or second shared child. A first shared child symbolizes the partners' commitment to their relationship and may confer the status and role of parent to one of the partners. A second shared child provides a full sibling to the first. 
Thus, in spite of the greater childrearing burden stepfamily couples may incur with each shared birth, they may be strongly motivated to have at least one or two children together.

Thomson and her colleagues (2002) provided a direct test of this hypothesis by controlling for a couple's combined number of children in estimating effects of stepfamily configuration on the couple's birth risk. In Austria, Finland, France and West Germany, they found decreasing birth risks with increasing combined parity, particularly after the couple had at least two children, consistent with increasing costs of rearing larger numbers of children. They also found, however, an increased birth risk for couples without shared children or with only one shared child, compared to couples whose children were all shared, consistent with the added value of shared births. A key assumption underlying inferences about child value, however, is that parents incur the same costs for rearing a shared child as they do for rearing a stepchild. If childrearing responsibilities are lower for stepchildren than for shared children, we would expect parity progressions in terms of total parity (hers + his + their) to be higher in stepfamilies even if there were no extra value of a prospective birth to be shared.

Shared children almost always live with both parents, but children from previous unions may not. Coresident children should matter more for the couple's further childbearing than do nonresident children. Even if couples receive financial help from a child's other parent, they must organize their household to accommodate the child and certainly spend more time and effort in caring for and supervising the child than if she/he lived elsewhere. Earlier studies have produced mixed findings on couple's fertility by stepchild coresidence. In Austria, coresident pre-union children were found to reduce the propensity of a first shared birth in second unions, while nonresident children had no impact (Buber \& Prskawetz 2000). In France, a woman's coresident pre-union children reduced a couple's childbearing while a man's nonresident children did not (Toulemon 1997). Conversely, no difference was found between the effects of coresident and nonresident children in Sweden: neither of them reduced the propensity of a first shared birth, and both reduced the propensity of a second shared birth (Vikat et al. 1999) ${ }^{1}$.

Because most children of separated or divorced parents live with their mothers, we would expect women's pre-union children to produce higher costs for a stepfamily couple than do men's children. In addition, gendered parenting may have its own unique effects on the costs of childrearing and the prospect of future births. First, women incur greater physical costs of

${ }^{1}$ In the Swedish data, the information on the partner's children was limited to the fact whether the partner had any children who joined the union with the respondent. 
pregnancy and birth; women who already are mothers may be less willing to undergo another pregnancy than men with the same number of children. Second, nonresident mothers have more contact with their children than do nonresident fathers (Seltzer \& Bianchi 1988). Third, if the couple's union ends, the woman with children from that union as well as previous unions is more likely to be rearing a larger number of children on her own, while the man has simply acquired nonresident children from several unions. Indeed, there is some evidence from earlier research that the man's pre-union children have a smaller negative effect on a couple's childbearing than woman's children do. Thomson (1997) found this for U.S. couples with two pre-union children and Toulemon (1997) for France. In the U.S., Stewart, Manning, and Smock (2001) found that men's nonresident children do not explain their subsequent fertility, and Stewart (2002) found that men's pre-union children have a non-significant effect on a couple's birth intentions while women's pre-union children do have an effect. However, there are also findings demonstrating that man's children have about the same fertility-reducing effect as the woman's: Thomson (1997) found this among couples with one pre-union child in the U.S., Buber \& Prskawetz (2000) in explaining first shared births in second unions in Austria, and Thomson and her colleagues (2002) in testing the parental status value of the first shared birth in Austria, Finland, France and West Germany. In Hungary during the state socialist system, pre-union children of a man reduced the propensity of a first shared birth in second union even more than those of a woman (Oláh 2001).

The difference in costs between coresident and nonresident children may be minimized when parents are required to provide substantial levels of support for and therefore have high levels of contact with their nonresident children and/or when the state provides high levels of public support to families with children. Similarly, differences between childrearing responsibilities related to women's versus men's children may also be reduced by societal-level conditions, such as material and ideological support for gender equality. Results from earlier country comparisons have not found support for these hypotheses. Thomson and colleagues (2002) found that the extra values of shared children to signal union commitment (first shared birth) and produce a full sibling (a second shared birth) did not appear stronger in countries with higher social provisions for childrearing; neither did they find evidence for greater value of maternal than of paternal status in any of the studied four countries (Austria, Finland, France, and West Germany). Similarly, Henz (2002) did not find gender differences in the parental status value in East Germany and West Germany. Both studies focused on certain values of shared children. It is possible, however, that country differences exist in the relative effects of coresident and nonresident children. 
Differences in responsibility for rearing children from previous unions should have a stronger effect on the risk of a couple's second and third shared birth than on the first. The first shared child provides two types of value - expressing relationship commitment and perhaps conferring parental status and role on one of the partners. The second shared birth provides only the value of a full sibling; in stepfamilies, the existence of at least one half-sibling may be sufficient. In addition, when the couple has coresident pre-union children, a second shared birth produces a family size that may place high demands on the couple for housing, income and the management of daily life. Several earlier studies have found that stepchildren have no or little influence on a couple's first shared birth (Griffith et al. 1985; Toulemon 1997; Vikat et al. 1999), in this way supporting the hypothesis on the commitment value of the first shared child. In more refined tests, Thomson and colleagues (2002) found support for the commitment value from four European countries and Thomson \& Li (2002) in the U.S. Results on the full-sibling value of a second shared child have been less consistent.

In sum, earlier evidence for our specification of the childrearing responsibility hypothesis is mixed. In some countries and some samples and with some specifications, differences are found between effects of coresident and nonresident stepchildren, and between women's and men's children. But results that do not support this hypothesis are reported in other countries with different samples and model specifications. Since many earlier studies had revealed differential effects of stepchildren by shared birth order, we consider all categories of children as categorical variables and do separate analyses by couples' number of shared children. This is a new step compared to earlier studies on coresidence and parentage effects of stepchildren where step-parity levels were distinguished at the level of no or any children of certain kind (Stewart et al 2000, Stewart 2002), where only first shared births were analyzed (Buber \& Prskawetz 2000), or where the information on partner's children was incomplete (Vikat et al. 1999). The other new feature of our study is that we compare the differential effects of coresident and nonresident stepchildren in countries with different policies relevant to stepfamily fertility.

Finland and Austria provide variability in social provisions for childcare and gender equality, which enables us to test hypotheses about how these issues influence responsibility for rearing coresident and nonresident, women's or men's children. Finland represents a social democratic family policy model geared to a dual-earner family and characterized by generous family allowances coupled with universal public child care services (Tyyskä 1995; Rønsen \& Sundström 1997; Forssén 1998; Rønsen 1998). For example, Finland has provided paid parental leave at $70-80 \%$ of income for about one year from the birth of the child, and mothers or fathers 
can stay at home with job security for up to three years ${ }^{2}$ (Social Insurance Institution 2000). The organization of childcare in Finland facilitates a more equal division of child-related household work between men and women (Bittman 1999). In Austria, organizational structures, school schedules, shopping hours, and child care services reflect a social and political belief in the fulltime homemaker (Schunter-Kleemann 1992; Buchmann \& Charles 1995), and family-related policies follow a female care model (Neyer 2003 forthcoming). There are considerable social provisions for families with children in Austria, like paid parental leave with job security, but benefits have been paid at a flat rate and are far lower than in Finland. In many ways, families with children have less flexibility in organizing their lives in Austria. (See Appendices in Hoem, Prskawetz, and Neyer 2001 for details.) Couples' time use on household work is more heavily on the woman's side in Austria than in Finland, even when both partners work for pay (Buber 2002; Statistics Finland 1994). Given these differences, we expect larger differences between the effects of coresident and nonresident stepchildren and between women's and men's children in Austria than in Finland.

\section{Data and Methods}

We use data from the Fertility and Family Surveys of Finland (Nikander 1998) and Austria (Prinz et al. 1998). The FFS surveys obtained complete birth and union histories from the respondent. A respondent's pre-union children can therefore be identified by comparing union start and end dates to children's birth dates. The union histories also include information on the number of children each partner had at the time of union formation and on the number of each partner's children who joined the couple at union formation. According to a recent crossEuropean comparison of combined union and childbearing histories using FFS, Finland and Austria are countries where women's stepfamily experience is at about the same level as in most other West European countries, with around 15\% of women entering a second union by age 35 and about half of them having children before that second union (Prskawetz et al. 2002).

In our preliminary analyses we discovered that the proportion of men's pre-union children reported as residing with the couple was unusually high in Finland, much higher than what was reported by women for their partners' children. We believe that Finnish men have underreported their nonresident children, particularly those with whom they have little contact (see also Rendall

\footnotetext{
${ }^{2}$ Before 1982 the principles of determining the allowance were different, the period of
} payment was shorter, and the average levels of benefits were about one third of that after 1982 . 
et al. 1999). Because differences between the effects of men's and women's children are a key focus in this study, we use the data that appear to be more reliable in identifying those children for both countries, i.e., data from female respondents (Tables 1 and 2). We selected only respondents who were likely to experience the cultural and structural contexts of those two countries that we study, and used information on women who were born in Austria or Finland, respectively.

We estimated hazard regression models of the risk of conception leading to a live birth, where conception was assumed to occur nine months before birth. Children were assigned to a union based on this conception date. We considered the respondent's children born twelve or fewer months before union formation as shared children, unless the child was conceived in a previous union. Children's coresidence was determined at the time of union formation; information on home-leaving of stepchildren after union formation was not available in the data. Observations were censored when a union dissolved and when the respondent reached age 45 after which childbearing is unlikely. We also censored at nine months before the interview, so that all conceptions observed resulted in a live birth. Finally, we censored records at a multiple birth, reasoning that two or more children born at the same time have a different meaning for parents than the same number born at different times do.

The baseline time parameter for the birth risk is specified as a linear spline with nodes at one, two, five and ten years. Observation usually begins at union formation, but if the woman was pregnant at union formation we start after the birth of a shared child. The effects of three control variables are also represented by linear splines: respondent's and partner's ages (nodes at 25, 30, 35 years for the woman's age, an added node at 40 for her partner's age), and calendar time (nodes at 1970 and 1980). Each of these control variables is a time-varying covariate.

All of our models also include the number of shared children $(0,1,2+$; time-varying) with alternative specifications of stepchildren. First, we estimate two baseline models, one in which we include the total number of pre-union children (hers + his) (Model 1), the other in which we limit the count to coresident pre-union children (Model 2a). Second, we test whether considering nonresident children in the count is necessary to explain a couple's birth risk. For this purpose we fit a model that includes both the number of coresident pre-union children and the number of nonresident pre-union children (Model 3a), in order to compare it to the model with only coresident children. Third, we test whether information on the coresidence of pre-union children is important when one knows the total number of children, by adding the number of coresident children to the model with total pre-union children (Model 4a). Fourth, we consider differences 
in coresidence effects by the number of pre-union and number of shared children. We distinguish effects of having one coresident child, one nonresident child, two coresident children, one preunion child of either category, and two nonresident children, separately for the risk of the couple's first and second shared birth. To test differences between the two countries, we used pooled data.

In parallel, we apply the above-described analytic strategy to separate the effects of the woman's and the man's pre-union children (Models 2b, 3b, and 4b). Although in most cases the nonresident children are those of the man, there were a few nonresident children to women and coresident children to men in both countries (Table 2). These numbers are too small for estimating their separate effects on the birth risk, but the coresidence of a pre-union child is also not entirely determined by the parent's sex, and the effects of a woman's total number of preunion children are apparently not identical to those of her coresident pre-union children.

Apart from Model 2a, each model considers information on the couple's total parity (hers + his + theirs) in the sense that all the different kinds of children a couple may have are considered. We also explored an alternative specification of the models, including a variable total parity and adding the number of a certain kind of children on top of that. Coefficients from such models showed, for example, that at the same level of total parity, couples with more preunion children are more likely to have another child than couples whose all children are shared, and that at the same level of total and pre-union parity, the number of nonresident children increases the propensity of another birth. However, we chose to present the results in the way described in the previous paragraph, that is, to specify the different kinds of children as categories that add up to total parity.

All our statements about statistical significance and the $p$ values presented are based on the likelihood-ratio test of two nested models. The results are expressed as relative risks, which are the exponentiated values of regression coefficients. We used $a M L$ software to estimate the models (Lillard \& Panis 2000).

There are indications that Austrians may have an incentive to report or actually start living together quite some time after the birth of a first shared child, related to single mother benefits that are considerably higher than those for mothers who live with a partner in Austria (Neyer 1991). So there may be a number of Austrian children who are shared by the couple and born more than twelve months before the union (we considered children born twelve months before the start of a union and not in a previous union as shared). We have no direct way of determining whether the child was shared or not other than the timing of its birth in relation to the reported 
month of union formation. However, the fact that in $8 \%$ of first unions of Austrian women, she had a coresident child born more than twelve months before the union, compared to only $2 \%$ in Finland, is in line with the suggested union formation behavior. To check the robustness of our results with respect to the definition of a pre-union child, we also ran the models for Austria using the definition where all children born to the woman before her first union and living with the couple at union formation were considered as shared children.

\section{Results}

In line with results from several earlier studies, our analysis of Finland and Austria demonstrates that children born before a union have a large effect on fertility in that union, but this effect on fertility is smaller than the effect of shared children (Table 3). In Model 1 in Table 3 this difference appears from the comparison of relative risks by the number of shared children with those by the number of pre-union children. We tested the difference between the effects of those two categories of children in a separate model fitted to the couples with total parity one or more, and obtained $p<.01$ for both countries (not presented). Model 1 in Table 3 also shows that the reduction in birth risk by pre-union children was somewhat larger in Austria than in Finland, though not significantly when tested in the pooled data set.

When we consider only coresident pre-union children, we see their strong effect on childbearing in a union (Model $2 \mathrm{a}$ in Table 4). The reduction of fertility in a union related to coresident pre-union children is larger in Austria than in Finland ( $p=.02$ for the country difference). In both countries, however, it is necessary to consider also the nonresident pre-union children in the pre-union parity count, because both coresident and nonresident children have a significant effect when simultaneously included in a model (Model 3a in Table 4).

The relative risks estimated by Model 3a show that coresident pre-union children reduce fertility somewhat more than nonresident children do. To test whether the difference in the coefficients is significant, we fit Model 4a that includes both the total number of pre-union children and their coresidence, and compare it with Model 1 that does not include information about coresidence. In Finland, there was only a weak indication that a coresident pre-union child has a larger effect on fertility than a nonresident child does ( $p=.19$, Table 4). In Austria, on the contrary, coresident pre-union children reduced fertility in a union far more than the nonresident children did $(p=.02)$. Comparison of these models indicates that, overall, coresidence with preunion children matters more in explaining childbearing in Austria than in Finland, and the difference between countries in this respect is statistically significant $(p=.02)$. 
Since we expected to find the effects of pre-union children to vary by shared birth order we ran separate models for couples without shared children (to analyze the risk of a first shared birth) and for couples with one shared child (to analyze the risk of a second shared birth). Overall, the risk of first shared birth was lower when the couple had pre-union children. The differences in the effects on first shared birth by stepchild coresidence were not significant in Finland (Figure 1a, Table 6). The same applies for Austrian couples who had one pre-union child. Among Austrian couples with two pre-union children, however, the differences in the risk of first shared birth by coresidence with pre-union children were quite substantial. Two coresident pre-union children reduced the risk of the first shared birth to less than a half of the level of couples who did not have pre-union children, while two nonresident children did not reduce the risk of first shared birth almost at all.

The reduction in the risk of second shared birth associated with pre-union children was considerably larger than the corresponding reduction in the risk of first shared birth. In both countries, couples with coresident pre-union children had lower second birth risks than couples with the same number of nonresident pre-union children (Figure 1b, Table 6). In Finland, the differences by coresidence of pre-union children were smaller and not statistically significant, while in Austria, the risk of second shared birth in couples with coresident pre-union children was less than half of that in couples with the same number of nonresident pre-union children. In all, the parity-specific childbearing risks reveal that Austrian couples experience a substantial drop in fertility after they reach a two-child family (total of shared children and coresident preunion children). Note the low risk of first shared birth of couples with two coresident pre-union children and the low risk of second shared birth of couples with at least one coresident pre-union child (Figure 1).

By distinguishing the woman's and man's pre-union children instead of coresident and nonresident children the picture remained essentially the same: Both woman's and man's preunion children have an effect on fertility in a union (Model 3b in Table 5). As hypothesized, the woman's pre-union children reduced a couple's fertility more than the man's pre-union children did. In Finland, the woman's pre-union parity count $(0,1,2+)$ improved the model that included total pre-union parity at $p=.06$. In Austria, the fertility-reducing effect of the woman's children was considerably larger than in Finland: Fertility in a union was lower by $26 \%$ if one of the preunion children was the woman's, and was lower by $46 \%$ if at least two pre-union children were the woman's, net of the total number of pre-union children (distinguishing woman's children in total pre-union parity improved the model fit at $p<.01$ ) (Model $4 \mathrm{~b}$ in Table 5). 
The patterns of effects for specific configurations of woman's and man's pre-union children, and their variation by shared parity progression were close to the patterns described for coresident and nonresident children. The effects of woman's pre-union children resembled those of coresident children and the effects of man's children resembled those of nonresident children, which could be expected in view of the overlap in those classifications (Table 6).

Our alternative specification of pre-union children in Austria, allocating all children born before the first union as shared with the first partner, altered the results minimally. Because this specification did not alter the number of children belonging to the man and, except for a handful of cases did not alter the number of nonresident children, effects of such children on the birth risk did not change. However, the differences between effects of women's and men's children or between effects of coresident and nonresident children were a little larger than in the original specification. Thus, the possibility that Austrian women delay cohabitation with the father of their first child would strengthen our inference that country differences in childrearing costs are reflected in different patterns of stepfamily childbearing.

\section{Summary}

The main results of the analysis can be summarized as follows:

- It is necessary to consider the nonresident pre-union children and children of the male partner in the pre-union parity count, because both coresident and nonresident children as well as both woman's and man's have a significant effect on the couple's childbearing risk.

- Coresident pre-union children or woman's pre-union children have a larger effect on fertility in a union than nonresident or man's pre-union children, and shared children have a larger effect on subsequent childbearing than do pre-union children.

- In Austria, the reduction in a couple's fertility associated with pre-union children is larger than in Finland, in particular among couples who already have a shared child.

- The differences between the effects of coresident and nonresident children, and between the woman's and the man's children, are larger in Austria than in Finland.

\section{Discussion}

Overall, shared and stepchildren reduce the risk of a subsequent birth to couples. In line with the common finding to most stepfamily fertility studies, the reduction is larger with each 
shared child than with a stepchild, which we interpret as mainly resulting from a lower average cost of rearing a stepchild compared to rearing a shared child. We found, as hypothesized, larger effects of coresident pre-union children than of nonresident children, and larger effects of woman's pre-union children than of man's. The differences were most pronounced in Austria where public supports for childrearing and gender equality are lower than in Finland.

The lack of or small difference between the effects of coresident and nonresident children in Finland is in line with those reported previously for Sweden (Vikat et al. 1999), consistent with the cultural and policy similarities of those two countries. The considerable difference we found in effects of coresident and nonresident pre-union children in Austria is in accordance with an earlier analysis of first births in second unions in this country (Buber \& Prskawetz 2000). In our study, we could reveal additional features in our parity-specific analysis, namely, that the contrast between the effects of coresident and nonresident children is even larger for second shared births, and that Austrian couples who have two children in the household, whether shared or not, have markedly lower birth risk than couples with a smaller number of children in the household.

It is plausible that this difference between Finland and Austria may be related to the different childcare and school arrangements in those countries, as well as to the wider range of options that Finnish women have for combining childbearing and gainful employment. Since the responsibility for arranging the everyday lives of children assumes more time use from the family side in Austria, there may be more grounds to limit the number of children currently living in the household there than in Finland where public childcare and schools are organized for the needs of a family where both parents are working outside the home.

The fact that the division of childrearing responsibilities between mothers and fathers is more on the mothers' side in Austria than in Finland may also explain the result that the contrast between the fertility-reducing effects of woman's and man's pre-union children is larger in Austria than in Finland. The main difference between the two countries lay in the fact that Austrian women seemed to adhere to a lifetime number of two children. After achieving this parity, childbearing risks plummeted regardless of how many of the two were shared with the current partner and how many pre-union children the man had.

Jaakkola \& Säntti (2000) reported that in a Finnish stepfamily, quite some contact between members of the "old" and "new" family is maintained in Finland, though it gradually diminishes depending on whether the new couple marries and has shared children. Of the children who have lived in mother's new family less than five years, $44 \%$ see their biological father at least once a 
month, while $25 \%$ do not meet their father at all. After more than ten years in a new family, the share of those who do not meet the father increased to $45 \%$. More than half of the stepparents participate substantially in bearing the costs related to the upbringing of the partner's children. At the same time it has been found in Austria that the contact of fathers with their children after separation or divorce are strongly reduced (Wilk 1999), although the financial support from the biological father to the child who lives with the mother may be large (Mottl 1996). It may be the case that women in Finland feel that they share the responsibilities for bringing up a pre-union child to some extent with the father of that child, while Austrian women may have a larger share of everyday responsibilities on their side and this may reduce their wish for another child.

Although our empirical results supported the hypotheses about contextual effects, there may also be other reasons why the step-parity effects differ between Finland and Austria, in addition to the differentials in family policy and gender relations. For a more detailed analysis of the mechanism of how these contextual differences operate through experiences on the couple level, we would need to address individual-level information on both partners' employment and other characteristics.

We also found support for the hypothesis that pre-union children's coresidence and parentage configuration made more difference for second shared births to the couple than to the first. This was apparent in particular in Austria, but the patterns of the effects in Finland were also consistent with this hypothesis, though not backed up with statistical significance. We see two factors that simultaneously contribute to this finding. As earlier research has demonstrated, the first shared child is a signal of the couple's commitment to the relationship and pre-union children have less influence on it. At the same time, issues of coresidence become more important in higher-order total (her + his + their) parity progressions as they determine the family size the couple would have to cope with when considering their further childbearing. The fact that the latter effect was more apparent in Austria is consistent with the hypothesis of relatively higher costs of children there compared to Finland.

Our analyses provided further evidence that in addition to a couple's total parity, the parentage and coresidence with their children has an effect on their childbearing. In particular, our study demonstrated that these effects vary between different social policy contexts. We used coresidence and gender of the parent as a measure of a couple's responsibility for that pre-union child, and these measures apparently capture important dimensions of responsibility, however, more detailed measures are needed to disentangle the association with childbearing decisions of various social, economic, and psychological aspects of relationship with stepchildren. Complex 
union and childbearing careers are on a rise, and our study demonstrates the importance of considering this in future fertility research.

\section{Acknowledgments}

We wish to thank Gerda Neyer for her helpful comments on this paper, Isabella Buber, Amy Godecker and Jan M. Hoem for their contribution in setting up the original data for event history modeling, and Statistics Finland and the Austrian Institute for Family Studies for their permission to use the national FFS data files on which this study is based. Support for the research was provided by U.S. National Institute of Child Health and Human Development grant HD20491, NICHD center grant HD05876, and the authors' respective institutions.

\section{References}

Bittman M 1999. Parenthood without penalty: Time use and public policy in Australia and Finland. Feminist Economics 5 (3): 27-42

Buber I 2002. The influence of the distribution of household and childrearing tasks between men and women on childbearing intentions in Austria. MPIDR Working-Paper WP 2002-004. Available at http://www.demogr.mpg.de/papers/working/wp-2002-004.pdf

Buber I, Prskawetz A 2000. Fertility in second unions in Austria: Findings from the Austrian FFS. Demographic Research [online] 2000; 3. Available at http://www.demographic-research.org/Volumes/Vol3/2

Buchmann M, Charles M 1995. Organizational and institutional factors in the process of gender stratification: Comparing social arrangements in six European countries. International Journal of Sociology 25 (2): 66-95

Forssén K 1998. Children, Families and the Welfare State: Studies on the Outcomes of the Finnish Family Policy. STAKES Research Reports, No. 92. 178 pp. Helsinki: STAKES - National Research and Development Centre for Welfare and Health

Griffith JD, Koo HP, Suchindran CM 1985. Childbearing and Family in Remarriage. Demography 1985; 22: 73-88

Henz U 2002. Childbirth in East and West German stepfamilies: Estimated probabilities from hazard rate models. Demogrphic Research [online] 2002; 7. Available at http://www.demographicresearch.org/Volumes/Vol7/6/7-6.pdf.

Hoem JM, Prskawetz A, Neyer G 2001. Autonomy or conservative adjustment? The effect of public policies and educational attainment on third births in Austria. MPIDR working-paper WP 2001-016. Available at http://www.demogr.mpg.de/Papers/Working/wp-2001-016.pdf. Published without appendices in Population Studies 55: 249-261

Jaakkola R, Säntti R 2000. Uusperheitten lapset ja vanhemmat: perheitten rakenne, toiminta ja talous [Parental responsibility for children in reconstituted families]. Oikeuspoliittisen tutkimuslaitoksen julkaisuja [Publications of the Finnish National Research Institute of Legal Policy], No. 174. 96 pp. Summary in English

Lillard LA, Panis CWA 2000. aML Multilevel Multiprocess Statistical Software, Release 1.0. Los Angeles, California: EconWare

Mottl I 1996. Kindersunterhalt, Obsorgeregelungen und Besuchsrecht bei Ehescheidung [Child maintenance, care rules and visiting rights after divorce]. In: U. Aichhorn (ed.), Frauen \& Recht [Women and Law], pp. 331394. Vienna/ New York: Springer

Neyer G (ed.) 1991. Risiko oder Sicherheit. Mutterschutzleistungen in Oesterreich. Forschungsberichte aus Sozialund Arbeitsmarktpolitik 38. Vienna. [Risk or security? Maternity-leave regulations in Austria. Research Reports of Social and Labor Market Policy 38. Vienna]

Neyer G 2003 (forthcoming). Austria: Introduction. In: Flora P \& Bahle Th (eds.): Family Change and Family Policies in Europe. Oxford University Press: Oxford.

Nikander T 1998. Fertility and Family Surveys in Countries of the ECE Region, Standard Country Report, Finland. New York: United Nations 
Oláh LSz 2001. The first shared birth in second unions in Sweden and Hungary: A gender perspective. In Oláh LSz, Gendering Family Dynamics: The Case of Sweden and Hungary. Stockholm University Demography Unit Dissertation Series, 3. Stockholm University

Prinz C, Lutz W, Nowak V, Pfeiffer C 1998. Fertility and Family Surveys in Countries of the ECE Region, Standard Country Report, Austria. New York: United Nations

Prskawetz A, Vikat A, Philipov D, Engelhardt H 2002. Pathways to stepfamily formation in Europe: Results from the FFS. MPIDR Working-Paper WP-2002-046. Rostock: MPIDR

Rendall MS, Clarke L, Peters HE, Ranjit N, Verropoulou G. Incomplete reporting of men's fertility in the United States and Britain: A research note. Demography 1999; 36 (1): 135-144

Rønsen M, Sundström M. 1997. Women's Return to Work After First Birth in the Nordic Countries -- Full Time or Part Time? Stockholm Research Reports in Demography 112. Stockholm University

Rønsen M 1998. Fertility and public policies: Evidence from Norway and Finland. Documents 98/12. Oslo: Statistics Norway

Schunter-Kleemann S 1992. Wohlfahrtsstaat und Patriarchat - Ein Vergleich europäischer Länder. In: S SchunterKleemann (ed), Herrenhaus Europa - Gesclechterverhältnisse im Wohlfahrtsstaat, pp 141-327. Berlin: Sigma

Seltzer JA, Bianchi SM 1988. Children's contact with absent parents. Journal of Marriage and the Family 50: 663677

Social Insurance Institution 2000. Statistical Yearbook of the Social Insurance Institution, 1999. Helsinki: KELA

Statistics Finland 1994. Suomalainen perhe [The Finnish Family]. Population 1994:5. Helsinki: Statistics Finland

Stewart SD 2002. The effect of stepchildren on childbearing intentions and births. Demography 39 (1): 181-197

Stewart SD, Manning WD, Smock PJ 2001. Nonresident fathers' new family formation: The effect of investments on nonresident children. Paper at the 2001 meetings of the PAA, Wasington, DC, 29-31 March 2001

Thomson E 1997. Her, His and Their Children: Influences on Couple Childbearing Decisions. National Survey of Families and Households Working Paper \#76, Center for Demography and Ecology, University of Wisconsin-Madison, Madison, WI.

Thomson E, Hoem JM, Vikat A, Prskawetz A, Buber I, Toulemon L, Henz U, Godecker AL, Kantorova V 2002. Childbearing in Stepfamilies: How Parity Matters. In Klijzing E, Corijn M (eds), Fertility and Partnership in Europe: Findings and Lessons from Comparative Research. Volume II. Geneva/New York: United Nations: forthcoming

Thomson E, Li J-CA 2002. Her, his and their children: Childbearing intentions and births in stepfamilies. Center for Demography and Ecology, University of Wisconsin-Madison, Madison, Wisconsin

Toulemon L 1997. The Fertility of Step-families: The Impact of Childbearing before the Current Union. Paper presented at the Annual Meeting of the Population Association of America, Washington, DC.

Tyyskä V 1995. The Politics of Caring and the Welfare State: The Impact of the Women's Movement on Child Care Policy in Canada and Finland, 1960-1990. ). Annales Academiae Scientiarum Fennicae Series B 277: 15-226

Vikat A, Thomson E, Hoem JM 1999. Stepfamily fertility in contemporary Sweden: The impact of childbearing before the current union. Population Studies 1999; 53: 211-225.

Wilk L 1999. Scheidung und Trennung von Partnerschaften [Divorce and union disruption]. In: Österreichische Familienbericht 1999 [Austrian Family Report], pp. 275-291. Vienna: Bundesministerium für Umwelt, Jugend, und Familie 
Table $1 \quad$ Samples, Fertility and Family Surveys of Finland and Austria

\section{Survey year}

$\begin{array}{rr}\text { Finland } & \text { Austria } \\ 1989 & 1995 / 1996 \\ 22-46 & 20-54 \\ 3,553 & 3,226 \\ 8,903 & 7,962\end{array}$

Age range of female respondents at interview

Analytic sample: female respondents with at least one union, excluding foreign-born women

8,903

7,962 
Table 2 Number of union/ birth-interval spells by the number of shared and pre-union children at the start of a spell

Finland

Austria

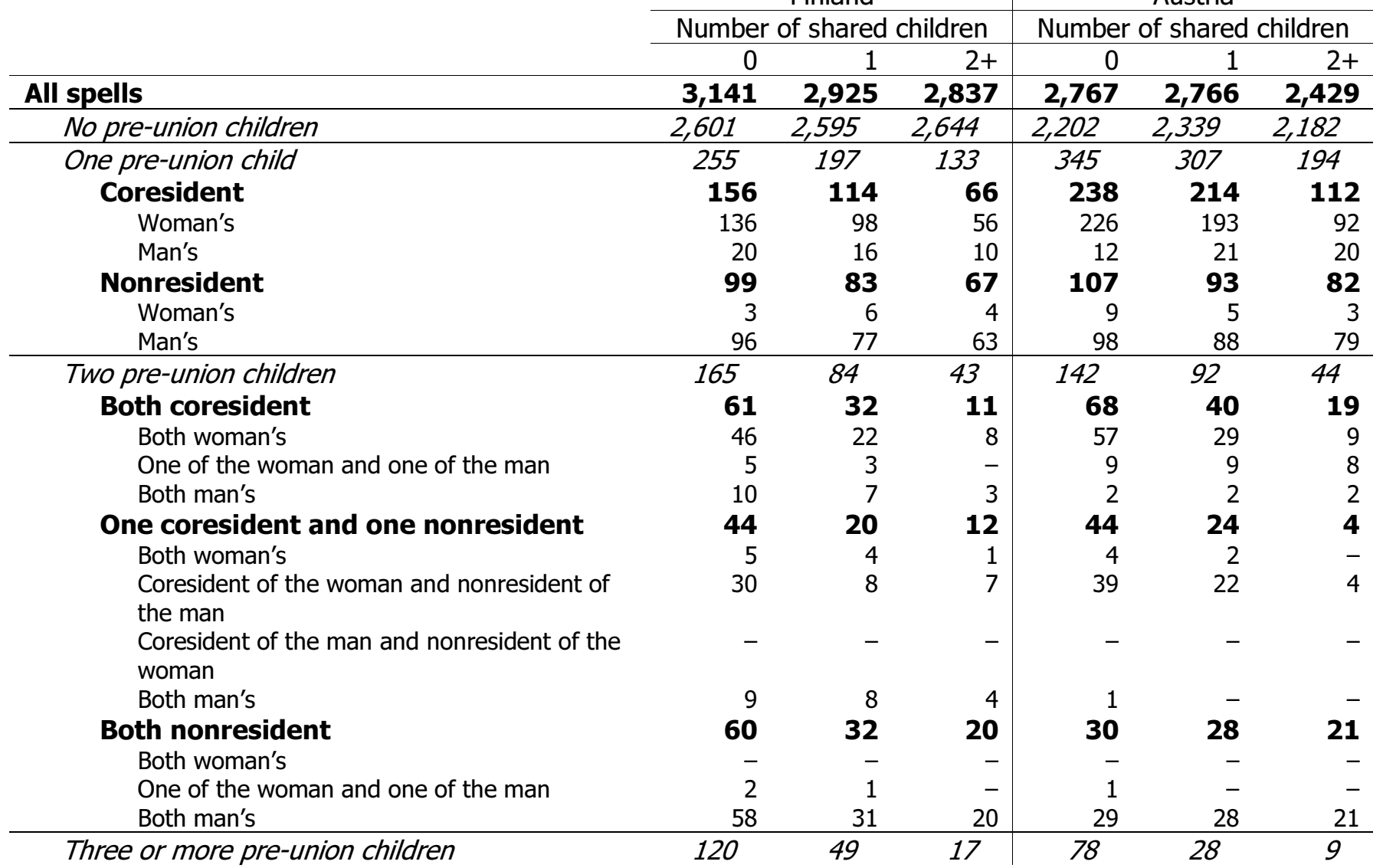

Note: The union/ birth-interval spells are time periods when the couple is characterized by a particular distinct combination of the time-varying covariates, here by the number of shared and pre-union children. The spells of couples without shared children start at union formation, however, if the woman was pregnant with the first shared child at union formation the spell starts at the birth of that child. All other spells start at the birth of a shared child. Coresidence with pre-union children was defined at the start of each union. 
Table 3 Full parameters (relative risks or spline gradients) of Model 1 and their significance level

Model 1

\begin{tabular}{cl} 
Finland & Austria \\
\hline Relative & risk \\
1.0 & 1.0 \\
$\mathbf{0 . 7 5}$ & $\mathbf{0 . 7 5}$ \\
$\mathbf{0 . 2 3}$ & $\mathbf{0 . 2 4}$ \\
$\mathbf{0 . 1 7}$ & $\mathbf{0 . 1 8}$ \\
1.0 & 1.0 \\
$\mathbf{0 . 7 5}$ & $\mathbf{0 . 7 1}$ \\
$\mathbf{0 . 6 9}$ & $\mathbf{0 . 5 8}$ \\
$\mathbf{0 . 5 1}$ & $\mathbf{0 . 3 5}$
\end{tabular}

Linear splines

Duration from previous birth or from union formation, years

Spline gradient

$0-1$

0.331

0.225

$1-2$

$-0.064$

2-5

$-0.137-0.183$

5-10

$-0.181-0.189$

10 or more

$-0.207 \quad-0.087$

Woman's age

less than 25

$-0.016 \quad 0.034$

25-30

$0.007 \quad-0.030$

30-35

$-0.055 \quad-0.078$

35-44

$-0.167 \quad-0.255$

Man's age

less than 25

$\begin{array}{ll}0.059 & 0.059\end{array}$

25-30

$0.012 \quad 0.007$

30-35

$-0.006$

0.011

35-40

$-0.033$

$-0.034$

40 or more

$-0.006$

0.008

Calendar year

1954-1970

$-0.088 \quad-0.104$

1970-1980

$\mathbf{0 . 0 1 9}-0.005$

1980 or later

$-0.058-0.011$

Constant (intercept)

$-0.587-0.566$

Log likelihood

$-22464.59-19361.98$

Notes: The effect of a duration from previous birth or union formation, woman's and man's age, and calendar year are all defined by means of linear splines. The parameters of the linear splines show gradient between one node and the next instead of referring to a single reference category.

Relative risks are given in boldface when they are significantly different from the reference category $(p<.05)$. In the case of linear splines, boldface is used when the gradient between two nodes is significantly different from zero. 
Table 4 Relative birth risks in a union by the number and residence of pre-union children, and likelihood ratio tests

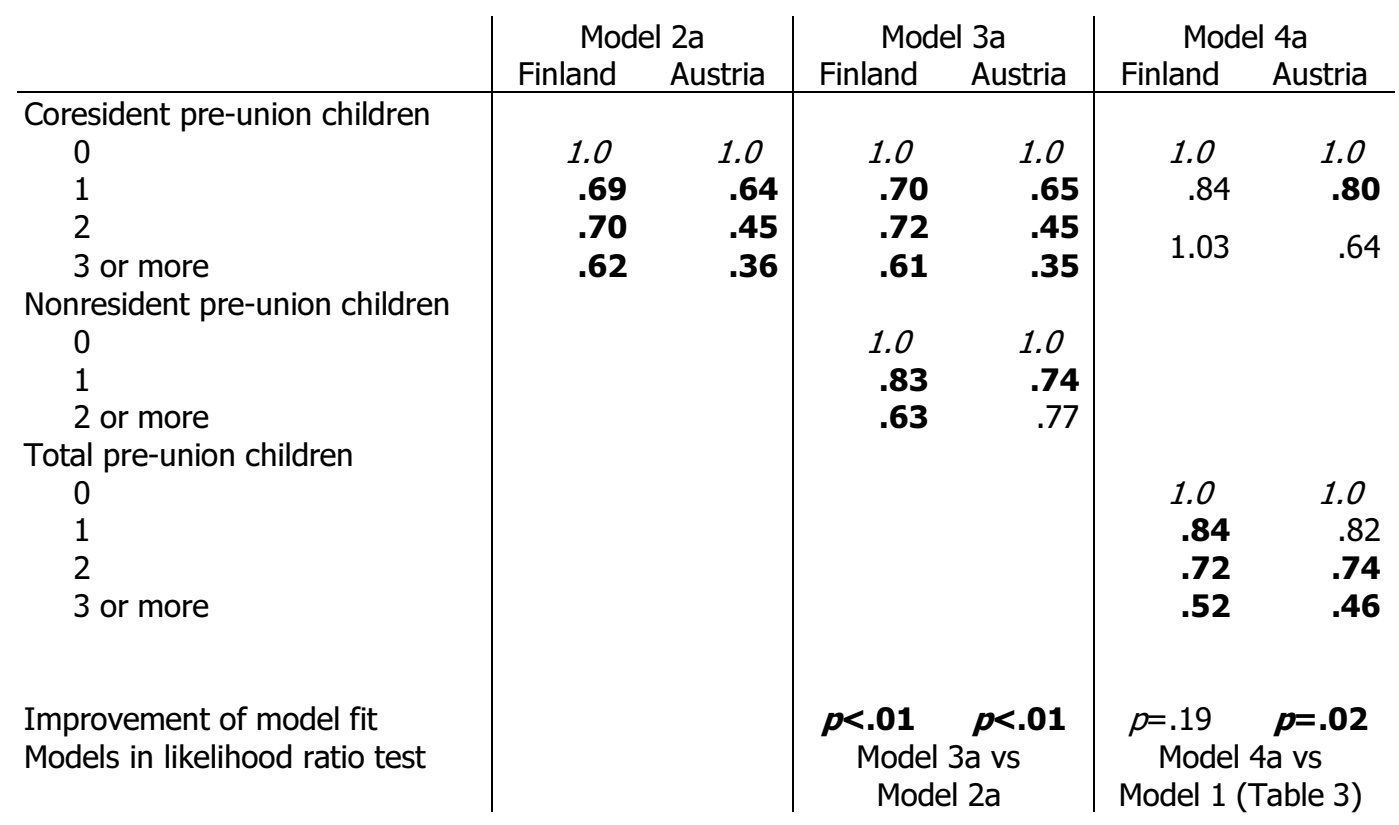

Notes: In addition to the variables in the table, all models include the following control variables: duration from union formation or birth (baseline time parameter), respondent's and partner's ages, calendar time, and the number of couple's shared children.

The reference category is indicated by a risk of 1.0 in italics.

Relative risks are given in boldface when they are significantly different from the risk of the reference category $(p<.05)$.

In Model 4, the highest category of coresident/ woman's children is two or more. 
Table 5 Relative birth risks in a union by the number and parentage of pre-union children, and likelihood ratio tests

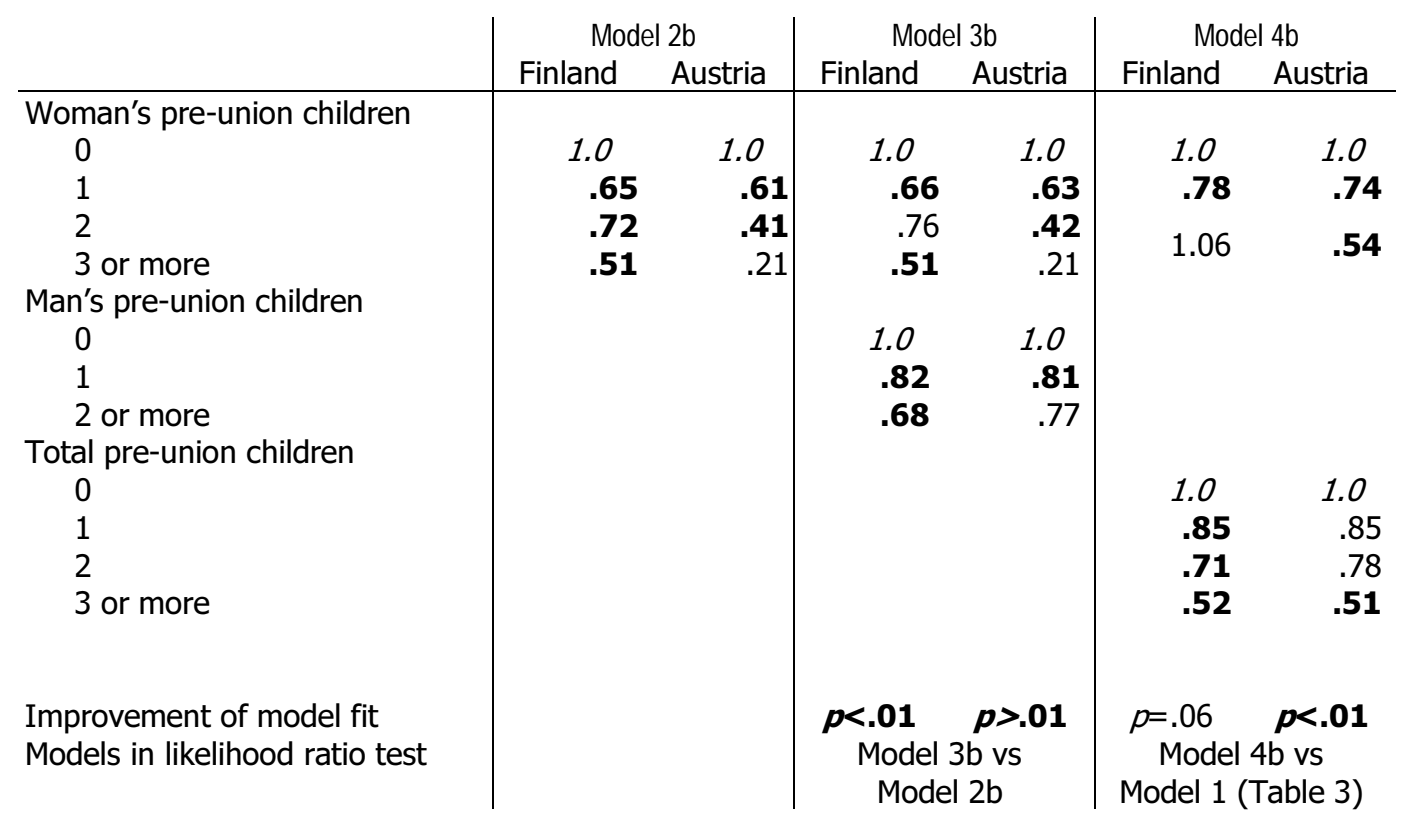

Notes: See Table 4. 
Table 6 Relative risks of first and second shared births by number, coresidence, and parentage of pre-union children, and the relevant significance tests. Data presented in Figures 1 and 2.

Number and residence of pre-union children

\begin{tabular}{|c|c|c|c|}
\hline \multicolumn{2}{|c|}{$\begin{array}{l}\text { Relative risk of the } \\
\text { first shared birth }\end{array}$} & \multicolumn{2}{|c|}{$\begin{array}{l}\text { Relative risk of the } \\
\text { second shared } \\
\text { birth }\end{array}$} \\
\hline Finland & Austria & Finland & Austria \\
\hline 1.00 & 1.00 & 1.00 & 1.00 \\
\hline 0.7 & 0.88 & & 0.41 \\
\hline 0.87 & 0.79 & 0.75 & 0.62 \\
\hline $\begin{array}{r}p=.29 \\
p=.\end{array}$ & $\begin{array}{l}p=.51 \\
46\end{array}$ & $\begin{array}{r}p=.27 \\
p=\end{array}$ & $\begin{array}{c}p=.03 \\
58\end{array}$ \\
\hline 0.8 & 0.46 & 0.63 & 0.45 \\
\hline 0.6 & 0.7 & 0.3 & 0.16 \\
\hline 0.71 & 0.92 & 0.76 & 0.70 \\
\hline $\begin{array}{r}p=.68 \\
p<1\end{array}$ & $\underset{01}{p<.01}$ & $\begin{array}{r}p=.68 \\
p=\end{array}$ & $\underset{31}{p=.01}$ \\
\hline 1. & 1.0 & 1. & 1.00 \\
\hline 0 & 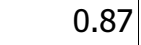 & 0.54 & 0.3 \\
\hline 0.87 & 0.81 & 0.81 & 0.73 \\
\hline $\begin{array}{r}p=.23 \\
p=.\end{array}$ & $\begin{array}{l}p=.64 \\
52\end{array}$ & $\begin{array}{r}p=.05 \\
p=\end{array}$ & $\underset{66}{p<.01}$ \\
\hline 0.8 & 0.4 & 0.70 & 0.30 \\
\hline 0 & & 0.3 & 07 \\
\hline 0.80 & 0.81 & 0.62 & 0.73 \\
\hline $\begin{array}{r}p=.93 \\
p=.\end{array}$ & $p=.04$ & $\begin{array}{r}p=.87 \\
p=\end{array}$ & $\begin{array}{l}p=.03 \\
12\end{array}$ \\
\hline
\end{tabular}

\section{Parentage models}

(1) no pre-union children (reference category)

(2) one woman's child

(3) one man's child

LR test for the difference between (2) and (3)

LR test for the country difference in the difference between (2) and (3)

(4) two woman's children

(5) one of each kind

(6) two man's children

LR test for the difference between (4) and (6)

LR test for the country difference in the difference between (4) and (6)

Note: In addition to the variables in the table, all models include the following control variables: duration from union formation or from birth (baseline time parameter), respondent's and partner's ages, calendar time. Models were run separately for couples without shared children (risk of a first shared birth) and for couples with one shared child (risk of a second shared birth).

Tests for the country differences were estimated using pooled data. The models in these tests included the same control variables as the single-country models, and additionally a dummy variable for country and its interaction with the total number of pre-union children. 
Figure 1 Relative risks of first and second shared births of a couple by the number and residence of pre-union children, Finland and Austria, data from the female respondents to FFS

a) Risk of first shared birth

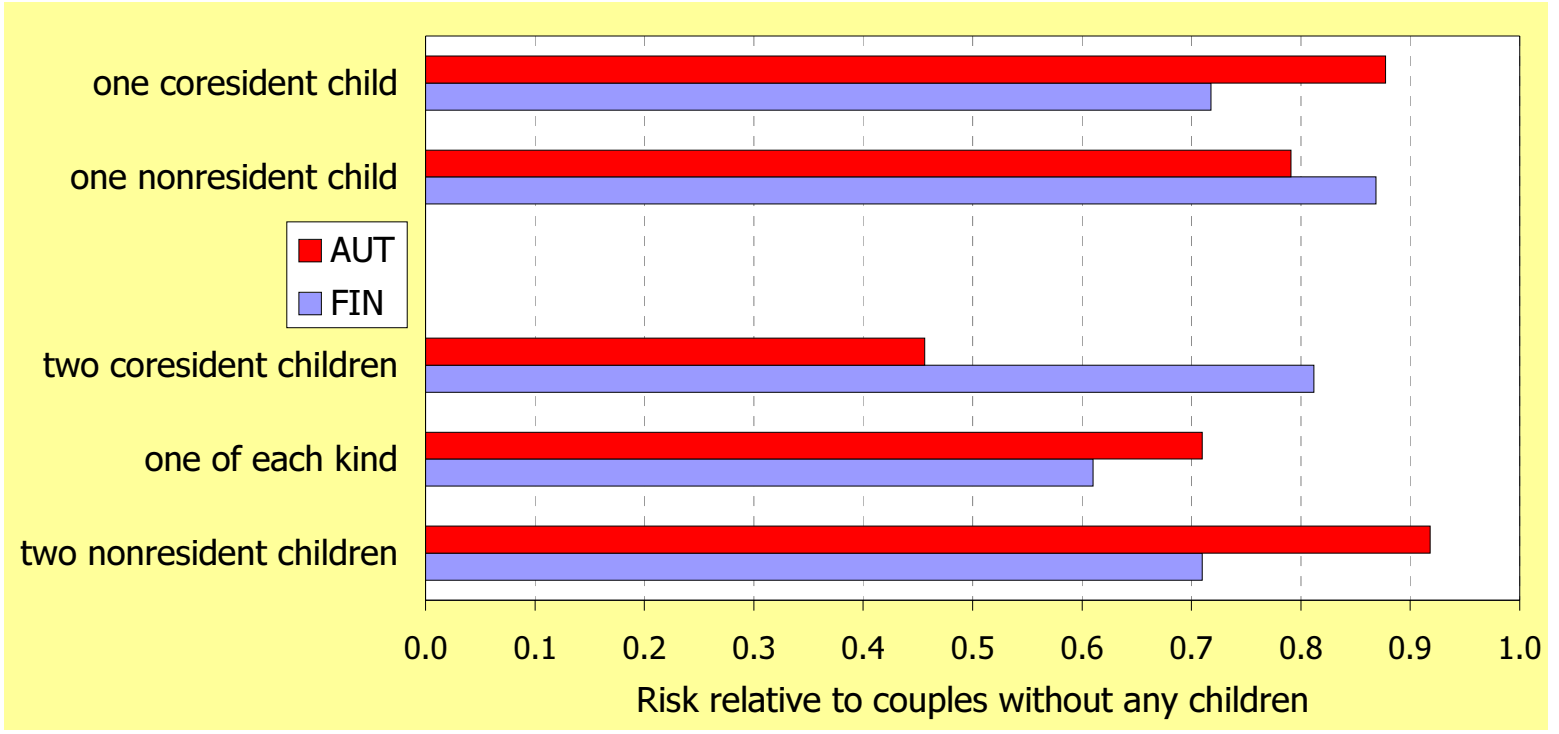

b) Risk of second shared birth

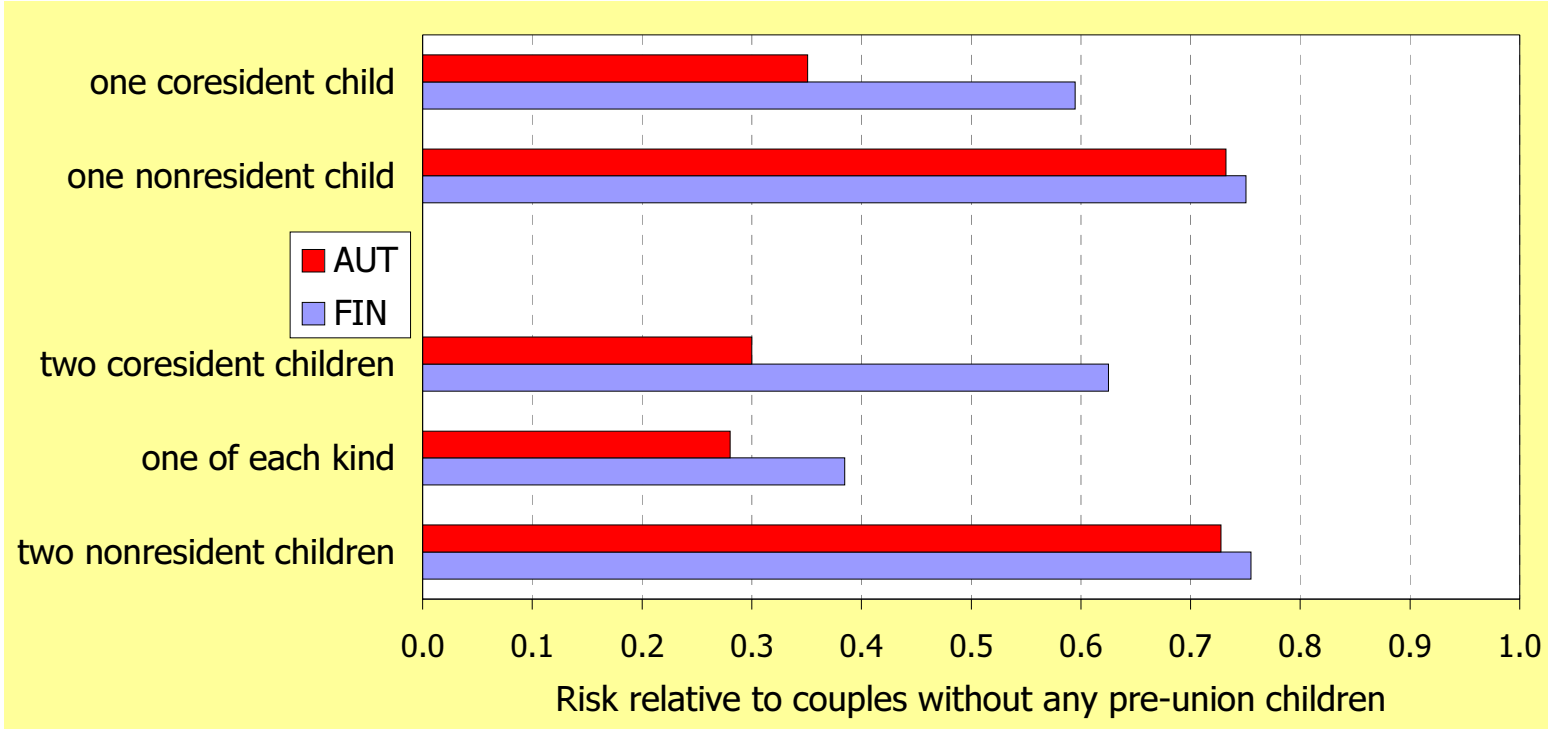

Note: The graphs are drawn from the data in Table 6. 